\title{
Foam fractionation efficiency of a vacuum airlift-Application to particulate matter removal in recirculating systems
}

\author{
Bertrand Barrut $^{\mathrm{a}}$, Jean-Paul Blancheton ${ }^{\mathrm{b}, *}$, Myriam Callier $^{\mathrm{b}}$, Jean-Yves Champagne ${ }^{\mathrm{c}}$, Alain Grasmick $^{\mathrm{d}}$ \\ ${ }^{a}$ ARDA, Station Marine du Port, Port Ouest, Hangar 10, 97420 Le Port, Reunion \\ ${ }^{\mathrm{b}}$ IFREMER, Station d'Aquaculture Expérimentale, Laboratoire de Recherche Piscicole de Méditerranée, Chemin \\ de Maguelone, 34250 Palavas-les-Flots, France \\ ${ }^{c}$ LMFA, UMR CNRS 5509, Université de Lyon, Ecole Centrale de Lyon, Université Lyon 1, INSA de Lyon, ECL, \\ 20, Avenue Albert Einstein, 69621 Villeurbanne Cedex, France \\ Institut Européen des Membranes, UMR CNRS 5635, Université Montpellier II, CC005, Place Eugène Bataillon, \\ 34095 Montpellier Cedex 05, France
}

*: Corresponding author : Jean-Paul Blancheton, tel.: +33467130412 ; fax: +33 467130458 ; email addresses : Jean.Paul.Blancheton@ifremer.fr ; jpblanch@ifremer.fr

\begin{abstract}
:
The accumulation of particulate organic matter (POM) in recirculating aquaculture systems (RAS) has become an important issue with the intensification of finfish production. The objective of this study was to assess the foam fractionation efficiency of a vacuum airlift in different conditions (POM concentrations, airflow rates, bubble sizes, water renewal rates and feed addition). In sea water, the vacuum airlift allowed removing $20 \%$ of the initial POM concentration per hour (foam fractionation efficiency), corresponding to a 20.7 -fold concentration factor between the tank and the foam. In rearing conditions, efficiency increased with decreasing water renewal rate or increasing POM concentration. An increase in airflow rate from 10 to $80 \mathrm{~L} \mathrm{~min}^{-1}$ in the vacuum airlift significantly decreased foam fractionation efficiency when feed was added to the water. The impact of feeding was only observed with high airflow rates where bubble coalescence occurred. Calculated POM production by fish ranged between 15.9 and $23.5 \mathrm{~g} \mathrm{~h}^{-1}$ and was equivalent to estimations based on feed conversion ratio (FCR). This indicated that all the POM produced was extracted by the vacuum airlift.
\end{abstract}

\section{Highlights}

The foam fractionation efficiency and the concentration factor of a vacuum airlift were calculated in sea water and in rearing sea water. The influence of airflow and water renewal rates on foam fractionation efficiency was measured. - In rearing conditions, differences in foam fractionation efficiency were observed before and after feeding. $>$ Particulate organic matter production by fish was calculated and found to be equivalent to estimations obtained using the feed conversion ratio (FCR).

Keywords: POM ; Vacuum airlift ; Foam fractionation efficiency ; RAS ; Aquaculture 


\section{Introduction}

The presence and accumulation of particulate matter (faeces, uneaten feed, parasites, and bacterial flocs) in Recirculating Aquaculture System (RAS) can decrease water quality, which may increase the stress of reared organisms (Timmons, 1994; Cripps and Bergheim, 2000; Rubio et al., 2002; Sharrer et al., 2005). Although there is little information available on safe level of particulate matter concentration, studies have already shown that above a concentration of $80 \mathrm{mg} \mathrm{L}^{-1}$, salmonid growth is significantly slowed down in RAS (Piper et al., 1982; Laird and Needham, 1988). As this safe concentration level clearly depends on each fish species, the main concern associated with particulate matter accumulation is the increase in the biological oxygen demand and the development of heterotrophic bacteria (Timmons and Ebeling, 2010). It is therefore necessary to remove these particles and control the quality of water.

Several types of particle separators, or clarifiers, are commercially available for integration into intensive aquaculture treatment system. Solids separation technology can be divided into mechanical and gravitational methods, but their efficiency is affected by particle size. Average particle size depends on fish species and size, on the type of feed used and on the hydraulic regime in the rearing tank, but usually ranges between 3 and $300 \mu \mathrm{m}$. However, most particles are smaller than $30 \mu \mathrm{m}$ (Cripps and Bergheim, 2000). The most popular method for mechanical particle separation involves the use of screens and rotating microscreens. Some problems encountered with this method include the difficulty to remove particles smaller than $50 \mu \mathrm{m}$ and poor flow capacities due to the small pore sizes which means that most of the fine solids remain even after passing through biological filters (Timmons, 1994; Summerfelt, 2006). Drum filters with $60 \mu \mathrm{m}$ screens allow around $50 \%$ of total particles to be eliminated with the other $50 \%$ usually being trapped in the biofilter (Cripps and Bergheim, 2000). The presence of particles reduces filter permeability and increases the growth of heterotrophic bacteria which oxidate organic matter. The consequences of this are (1) more frequent back-wash, (2) competition between autotrophic and heterotrophic bacteria for specific area and nutriments and (3) additional oxygenation (Blancheton, 2000; Blancheton et al., 2009). Use of drum filters with reduced porosity would entail higher energy 
costs, which is not viable for aquaculture applications. Sand filters are frequently used but they generate high head losses and require frequent maintenance (Summerfelt, 2006). Gravity sedimentation is also used as it is simple and highly energy-efficient (Rawat et al., 2011), however the process only works for large-sized and high density particles (Amaro et al., 2011; Chen et al., 2011). Sedimentation rates for particle sizes between 10 and $50 \mu \mathrm{m}$ are slow and average settling velocity is below $1 \mathrm{~m} \mathrm{~h}^{-1}$ (Brambilla et al., 2008). Therefore, Particulate Organic Matter (POM) is generally first extracted by sedimentation of the larger particles (faeces and uneaten feed $>100 \mu \mathrm{m}$ ) and then by mechanical filtration of the smaller particles (30-100 $\mu \mathrm{m})$. Protein skimmers using foam fractionation can be used in addition to mechanical filtration to extract smaller particles and to relieve the mechanical filter in terms of efficiency and energy (Rubio et al., 2002; Sharrer et al., 2005; Summerfelt, 2006). Foam fractionation is a water treatment technology that can be easily added to water reuse systems to directly remove dissolved and fine suspended solids. The process of foam fractionation, also known as flotation, protein skimming, or air stripping, has been widely described by Timmons (1994), Summerfelt (1999) and Brambilla et al. (2008). It consists in injecting fine air bubbles into wastewater. Micron-sized air bubbles may attach to the surface of surface-active particles and carry them to the free surface, forming a concentrated layer of foam that is then removed from the wastewater for separation. Skimmers are usually preferred as they are cost-effective and easy to use (Timmons et al., 1995; Blancheton et al., 2007; Suzuki et al., 2008; Brambilla et al., 2008; Roque d'Orbcastel et al., 2009; Park et al., 2011). In rearing farms, foam fractionation allows the extraction of fine particles smaller than $30 \mu \mathrm{m}$ (Timmons, 1994; Chen et al., 1994). Muniain-Mujikaa et al. (2002) and Suantika et al. (2001, 2003) have shown that in rearing farms, only skimmers give rise to high quality water. The ability of skimmers to extract microparticles is also interesting in terms of biosecurity as they may be used to extract bacteria and viruses (Timmons, 1994, Suantika et al., 2001; Suzuki et al., 2008; Brambilla et al., 2008; Park et al., 2011). Other organisms such as toxic microalgae or parasites can also be extracted as they possess surface-active substances on their cell walls, which induces the formation of foam that may be collected (French et al., 2000; Teixeira and Rosa, 2006; Suzuki et al., 2008; Teixeira et al., 2010; Park et al., 2011).

Clarification of water by foam fractionation allows the reduction of UV irradiation for disinfection (Suzuki et al., 2008). Furthermore, injected micron-sized air bubbles also contribute to increasing aeration and $\mathrm{CO}_{2}$ stripping (Barrut et al., 2012).

However, flotation is dependent on bubble diameter, concentration of the solids, air-to-water ratio, surface chemistry of the solids, and the surfactant concentration in the water 
(Summerfelt, 1999). Timmons et al. (1995), Brambilla et al. (2008) and Park et al. (2011) have shown that skimming efficiency is reduced with the addition of feed to rearing water. This is due to the lipid content of feed which reduces the formation of foam. To limit this phenomenon, surface active agents may be used to increase the formation of foam (Keyes and Stover, 1992; Timmons et al., 1995; Brambilla et al., 2008), but this is not recommended for the food industry. Skimmers are more often used in shellfish aquaculture where the presence of proteins and polysaccharides in the rearing water is high, allowing better foam fractionation (Muniain-Mujikaa et al., 2002). Soluble proteins induce the formation of foam because proteins migrate toward the water surface and concentrate while reducing surface tension. The more soluble a protein, the more foam is formed (Frénot and Vierling, 2002). It is also assumed that surface-active substances such as polysaccharides and proteins not only generate foam on the water surface, but also change the interface of solids from hydrophilic to hydrophobic, which facilitates their concentration in the foam (Suzuki et al., 2008).

The interest of vacuum flotation has been widely described in chemical engineering for solidliquid separation, but there is no information concerning particulate removal in rearing water with the addition of vacuum on foam fractionation. The aim of this study was to evaluate the foam fractionation efficiency of a vacuum airlift for the removal of particulate matter from water and to study the effects of feed addition and water renewal on this efficiency.

\section{Materials and methods}

\subsection{Experimental set-up}

The experimental set-up is described in Figure 1. It comprised a $1000 \mathrm{~L}$ tank (1) open to the air and connected to a vacuum airlift provided by $\operatorname{COLDEP}^{\circledR}$ (2), composed of two concentric vertical transparent $6 \mathrm{~m}$-long PVC pipes. The outer diameter (OD) of the internal pipe was $160 \mathrm{~mm}$. The diameter of the external pipe was $315 \mathrm{~mm}$ (OD) along the first meter and $250 \mathrm{~mm}$ (OD) after the first meter and up to the top (Fig. 1). The top of the vacuum airlift was hermetically closed and connected to a vacuum pump (3) (BUSCH - Mink MM.1100.BV) with a maximal airflow of $60 \mathrm{~m}^{3} \mathrm{~h}^{-1}$. The vacuum created by the pump causes the water to rise in the internal pipe. A pressure gauge (4) ranging from -1 bar to 1 bar, connected to the frequency converter of the pump's electric motor, was used to control the 
pressure level and regulate water height in the vacuum airlift. At the top of the vacuum airlift, the water surface level was maintained over the internal tube (Fig. 1) to limit head losses when water flow passed from the internal to the external tube. The foam produced by air bubbling concentrates the particulate matter of the water. It was collected by overflowing from the external tube at the top of the vacuum airlift. The foam removal was enhanced by the addition of vacuum and then separated and stored in a $100 \mathrm{~L}$ tank (6) fitted with a valve at the bottom for sampling. The water in the downcomer tube flowed back to the pumping tank.

Figure 1

Air was injected close to the bottom of the inner tube using an electric compressor (5) (BECKER DT4.40K), which delivers a maximum of $40 \mathrm{~m}^{3} \mathrm{~h}^{-1}$ at a pressure of 1 bar. Two types of injectors were used: a ceramic diffuser working at a pressure of 0.5 bar which creates fine bubbles $(1 \mathrm{~mm})$ and a ceramic diffuser working at a pressure of 1 bar which creates microbubbles $(<1 \mathrm{~mm})$. Injected air pressure was controlled by a pressure gauge and airflow was measured using a rotameter (Key Instrument MR 3000 Series Flowmeter $\pm 5 \mathrm{~L} \mathrm{~min}^{-1}$ ).

\subsection{Experiment with addition of feed to sea water}

The separation and concentration capacities of the vacuum airlift were tested with the addition of feed consisting of fish pellets with a diameter of $2 \mathrm{~mm}$ (LE GOUESSANT - OMBRINE GROWER EXT-coul 2, $47 \%$ protein and $13 \%$ lipids). A $400 \mathrm{~g}$ portion of feed was added to sea water (35\%) and mixed using a submersible propeller pump for $24 \mathrm{~h}$ until the pellets were in suspension and nothing was settled in the tank. The vacuum airlift was started and the experiment lasted for $4 \mathrm{~h}$. Samples were collected at the beginning and end of the experiment, both from the circulating suspension and from the concentrate water (resulting from foam fractionation at the top of the column).

\subsection{Method to evaluate foam fractionation efficiency in rearing conditions}

To study the modification of foam fractionation efficiency in fish rearing conditions, the vacuum airlift was connected to a $15 \mathrm{~m}^{3}$ rearing tank operated with an hourly seawater renewal rate of $100 \%$. The vacuum airlift and all the devices used for analysis were the same to those described previously (sections 2.1 and 2.2). The livestock consisted of $200 \mathrm{~kg}$ of red 
drums (Sciaenops ocellata) with an average weight of $15 \mathrm{~g}$. The feed used was identical to that described previously (section 2.2). It was distributed automatically during $4 \mathrm{~h}$ with a daily feeding rate of $1 \%$ of total biomass. Samples were collected in the tank and at the outlet of the skimmer of the vacuum airlift before and $4 \mathrm{~h}$ after the feeding period. The effect of the variation of the tank water renewal on foam fractionation efficiency was evaluated at 3 different rates: $100 \%, 50 \%$ or $10 \%$.

\subsection{Methods to measure the concentration in POM}

To evaluate the concentration of the suspended solids, all samples were subjected to filtration using filters of $1.2 \mu \mathrm{m}$ porosity (nylon $\emptyset 47 \mathrm{~mm}$, WHATMAN®), weighed using a precision weighing balance (PRECISA 410AM-FR with an accuracy of $10^{-5} \mathrm{~g} \mathrm{~L}^{-1}$ ) and then rinsed with distilled water according to AFNOR T90-105 (2005) standards. The filters were put in a weighed aluminium cup and placed in a drying chamber for $24 \mathrm{~h}$ at $70^{\circ} \mathrm{C}$. The cup was then weighed again to quantify the dry weight (DW) of POM. The Concentration Factor (CF) was

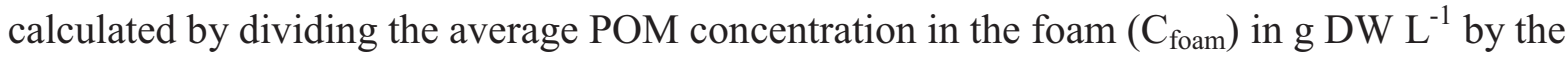
average POM concentration in the tank $\left(\mathrm{C}_{\text {tank }}\right)$ in $\mathrm{g} \mathrm{DW} \mathrm{L}^{-1}$ :

$$
C F=\frac{C_{\text {foam }}}{C_{\text {tan } k}}
$$

For the experiment involving feed addition to sea water, the total POM dry weight in the tank or in the extracted foam was calculated using the following equation:

$Q=C \times V$

with $\mathrm{Q}$ equal to the total POM dry weight in the tank (g DW) at the beginning $\left(\mathrm{Q}_{\mathrm{i}}\right)$ or at the end of the experiment $\left(\mathrm{Q}_{\mathrm{f}}\right)$ or in the foam $\left(\mathrm{Q}_{\text {foam }}\right), \mathrm{C}$ equal to the concentration of POM in the tank ( $g$ DW L $\left.{ }^{-1}\right)$ at the beginning $\left(\mathrm{C}_{\mathrm{i}}\right)$ or at the end of the experiment $\left(\mathrm{C}_{\mathrm{f}}\right)$ or in the foam $\left(\mathrm{C}_{\text {foam }}\right)$ and $\mathrm{V}$ equal to the volume of the tank $(\mathrm{L})$ at the beginning $\left(\mathrm{V}_{\mathrm{i}}\right)$ or at the end of the experiment $\left(\mathrm{V}_{\mathrm{f}}\right)$ or of the foam $\left(\mathrm{V}_{\text {foam }}\right)$ with $\mathrm{V}_{\mathrm{f}}=\mathrm{V}_{\mathrm{i}}-\mathrm{V}_{\text {foam. }}$. Foam fractionation efficiency was calculated by dividing the total POM dry weight of the foam by the POM dry weight in the water before beginning the experiment as follows: 


$$
\text { Eff }=\frac{Q_{\text {foam }}}{Q_{i}} \times 100
$$

\subsection{Methods to assess POM production by fish}

POM production by fish in the rearing tank was estimated with two different methods. The first method required the mass balance shown in Eq (4) using the results of POM concentration measurements in the foam and in the rearing tank:

$$
P_{P O M}=Q_{\text {foam }} C_{\text {foam }}+Q_{\text {out }} C_{\text {out }}-Q_{\text {in }} C_{\text {in }}
$$

with $\mathrm{P}_{\mathrm{POM}}$ equal to POM production by fish in $\mathrm{g} \cdot \mathrm{h}^{-1}, \mathrm{C}_{\mathrm{out}}$ equal to the POM concentration in the tank in $\mathrm{g} \cdot \mathrm{m}^{-3}, \mathrm{C}_{\text {in }}$ equal to the POM concentration in the makeup water, considered as insignificant, $Q_{\text {out }}=Q_{\text {in }}$, i.e. the water renewal rate of the rearing tank in $\mathrm{m}^{3} \cdot \mathrm{h}^{-1}, \mathrm{C}_{\text {foam }}$ equal to the POM concentration in the foam in $\mathrm{g} \cdot \mathrm{m}^{-3}$ and $\mathrm{Q}_{\text {foam }}$ equal to the foam extraction flow in $\mathrm{m}^{3} \cdot \mathrm{h}^{-1}$.

The second method was based on the Feed Conversion Ratio (FCR) values, i.e. the quantity of food necessary to produce one kilo of fish using Eq (5) given by Fauré (1983):

$$
P_{P O M}=Q_{\text {feed }}\left(\frac{33 \times F C R-20}{100}\right)
$$

with $\mathrm{Q}_{\text {feed }}$ equal to the hourly amount of feed given, namely $84 \mathrm{~g} \mathrm{~h}^{-1}$.

\section{Results and discussion}

\subsection{Foam fractionation efficiency on fragmented fish feed}

After 4 h, POM concentration decreased by a factor of 4.2 in the tank and increased by a factor of 20.7 in the foam, for an extracted volume of $160 \mathrm{~L}$, corresponding to a foam fractionation efficiency of $80 \%$ i.e. $20 \%$ per hour (Table 1 ). 
Table 1

Conversely to what is usually described in research literature (Timmons et al., 1995; Park et al., 2011), the addition of fish feed to water did not alter foam formation or decrease foam fractionation efficiency of the vacuum airlift.

\subsection{Foam fractionation efficiency in rearing conditions}

The amount of POM in the rearing water, principally made up of faeces produced by fish, increased by 2 - to 3 -fold after feeding (Fig. 2 and 3). An airflow rate of $80 \mathrm{~L} \mathrm{~min}^{-1}$ with both microbubble and fine bubble air injection, led to significant reduction in foam fractionation efficiency of the vacuum airlift after feeding with no significant differences being observed between the POM concentration in the tank and the POM concentration in the foam (Fig. 2). However, when the airflow rate was reduced to $10 \mathrm{~L} \mathrm{~min}^{-1}$, foam fractionation efficiency was not affected by the addition of feed to water since the POM concentration in the foam remained 4-fold more concentrated than in the tank. The POM concentration in the foam decreased from $33.3 \mathrm{mg} \mathrm{L}^{-1}$ to $12.8 \mathrm{mg} \mathrm{L}^{-1}$ when the airflow rate was increased from 10 to 80 $\mathrm{L} \min ^{-1}$.

\section{Figure 2}

In rearing conditions, with higher airflow rates and fine bubble air diffusion, bubbles rapidly coalesce when feed is added to the water, which leads to an increase in bubble size and a reduction in gas holdup (Barrut et al., 2012). These modifications in the functioning of vacuum airlifts lead to increased turbulence and limitation of foam formation, which reduces foam fractionation efficiency as described in the literature (Timmons et al., 1995; Park et al., 2011). In reducing the airflow rate and average bubble size through microbubbling, bubble coalescence was limited and foam fractionation efficiency was thus not affected by the addition of feed into the tank. These results have been obtained in sea water, in fresh water the efficiency would have probably been reduced as the average bubble size is larger than in sea water and foam formation reduced (Barrut et al., 2012).

The decrease of the water renewal rate in the rearing tank to $50 \%$ or to $10 \%$ induced, in both cases, a doubling of POM concentration in the rearing tank, before or after the addition of 
feed (Fig. 3). The reduction of the water renewal rate from 50 to $10 \%$ should have led to a 4fold increase of POM concentration in the tank. However, the POM concentration at the water renewal rate of $10 \%$, increased continuously and the steady state was not achieved (Fig. 4). In the foam, POM concentration increased by 2 - and 6 -fold when water renewal rates decreased from 100 to $50 \%$ and from 50 to $10 \%$, respectively, independently of feeding activity (Fig. $3)$.

Figure 3

Figure 4

The concentration factor was around 4 for water renewal rates of 100 and $50 \%$, before or after feeding, and over 10 for a water renewal rate of $10 \%$ (Fig. 5). In rearing sea water, the presence of surface-active substances such as proteins from fish mucus probably results in the interface of the particles changing from hydrophilic to hydrophobic (Suzuki et al., 2008). The particles are more easily trapped in the foam when the water renewal rate is reduced. Under these experimental conditions (low airflow rate and microbubbling), foam fractionation efficiency was not reduced by feeding. This result differs from some recently published studies using regular foam fractionators (Brambilla et al., 2008; Park et al., 2011). It could also be explained by the addition of vacuum which may have (1) modified the particulate surface, increasing solid-bubble interaction and facilitating particles removal and/or (2) increased the range of bubble sizes, enabling the removal of both particles and surface active molecules, known to limit foam fractionation efficiency of regular foam fractionators.

Figure 5

In rearing conditions, calculated POM production rates using Eq. (4) are comprised between 15.9 and $26.6 \mathrm{~g} \mathrm{~h}^{-1}$, irrespective of the water renewal rate (Table 2). For red drum (Sciaenops ocellatus), the FCR ranged from 1.2 to 1.6 (Lacroix and Fuchs, 1998). POM production rates estimated using Eq. (5) with FCRs of 1.2 and 1.6 are 16.3 and $27.3 \mathrm{~g} \mathrm{~h}^{-1}$, respectively. These estimated values are consistent with the values calculated and presented in table 2. Results indicate that the skimmer of the vacuum airlift was able to extract almost all the POM produced by the fish in the rearing tank. 
Table 2

\section{Conclusion}

In sea water, the vacuum airlift provided a foam fractionation efficiency of $20 \%$ per hour and a concentration factor of 20.7 which were not altered by the addition of feed to water. In rearing conditions, efficiency increased with reduced water renewal rates, i.e. with increased POM concentrations. However, an increase in airflow rate from 10 to $80 \mathrm{~L} \mathrm{~min}^{-1}$ led to an important reduction in foam fractionation efficiency after feeding due to massive bubble coalescence. POM production by fish was calculated and was equivalent to the estimation based on FCR, which means that the entire POM production was extracted by the vacuum airlift. The system can thus be considered as a promising tool for foam fractionation in RAS. However, additional work is required to accurately describe the types of POM removed from the water and to adapt the geometry of vacuum airlifts to various RAS designs.

\section{Acknowledgements}

We would like to thank Pierre Bosc from ARDA and the Réunion Region as long as the french National Association for Research and Technology (ANRT) for their financial support of the project. This work was made possible thanks to the cooperation of François René (IFREMER). We also wish to thank Julien Jacquety from COLDEP $^{\circledR}$ for all his assistance and hard work, and for providing the vacuum airlift.

\section{References}

Amaro, H.M., Guedes, A.C., Malcata, F.X., 2011. Advances and perspectives in using microalgae to produce biodiesel. Appl. Energ. 88, 3402-3410.

AFNOR, NF EN 872, 2005. Qualité de l'eau - Dosage des matières en suspension - Méthode par filtration sur filtre en fibres de verre. Indice de classement : T90-105. 
Barrut, B., Blancheton, J.P., Champagne, J.Y., Grasmick, A., 2012. Mass transfer efficiency of a vacuum airlift - Application to water recycling in aquaculture systems. Aquacult. Eng. $46,18-26$.

Blancheton, J.P., 2000. Developments in recirculating systems for mediterranean fish species. Aquacult. Eng. 22, 17-31.

Blancheton, J.P., Piedrahita, R., Eding, E.H., Roque d'orbcastel, E., Lemarié, G., Bergheim, A., Fivelstad, S., 2007. Intensification of land based aquaculture production in single pass and reuse systems. Chapter 2. In: Aquaculture Engineering and Environment, p. 21-47.

Blancheton, J.P., Bosc, P., Hussenot, J.M.E., Roque d'Orbcastel, E., Romain, D., 2009. Tendances pour la pisciculture européenne de demain : cages au large, systèmes en eau recirculée et systèmes intégrés. Cahiers Agricultures 18, 2-3, 227-234.

Brambilla, F., Antonini, M., Ceccuzzi, P., Terova, G., Saroglia, M., 2008. Foam fractionation efficiency in particulate matter and heterotrophic bacteria removal from a recirculating seabass (Dicentrarchus labrax) system. Aquacult. Eng. 39, 37-42.

Chen, S., Timmons, M.B., Bisogni, J.J., Aneshansley, D.J., 1994. Modelling surfactant remove in foam fractionation: I. Theoretical development. Aquacult. Eng. 13, 163-181.

Chen, C.Y., Yeh, K.L., Aisyah, R., Lee, D.J., Chang, J.S., 2011. Cultivation, photobioreactor design and harvesting of microalgae for biodiesel production: A critical review. Bioresource Technol. 102, 71-81.

Cripps, S.J., Bergheim, A., 2000. Solids management and removal for intensive landbased aquaculture production systems. Aquacult. Eng. 22, 33-56.

Fauré, A., 1983. Salmoniculture et Environnement, volume 1. Evaluation de la pollution rejetée par les salmonicultures intensives. CEMAGREF, Bordeaux, France, Etude n 16, 71 p. 
French, K., Guest, R.K., Finch, G.R., Haas, C.N., 2000. Correlating Cryptosporidium removal using dissolved air flotation in water treatment. Water Res. 34: 4116-4119.

Frénot, M., Vierling, E., 2002. Biochimie des aliments: diététique du sujet bien portant, Editions Doin, 297 p.

Keyes, W.W., Stover, J.E., 1992. Continuous soap skimmer, US Patent, 5, p. 137-643.

Lacroix, D., Fuchs, J., 1998. Aquaculture insulaire et tropicale. Editions Ifremer, Actes de colloques, $105 \mathrm{p}$.

Laird, L.M., Needham, T., 1988. Salmon and trout farming. Ellis Horwood, Chichester, West Sussex, England, 271 p.

Muniain-Mujikaa, I., Gironesa, R., Tofiño-Quesadaa, G., Calvob, M. and Lucenaa, F., 2002. Depuration dynamics of viruses in shellfish, Int. J. Food Microbiol. 77, Issues 1-2, p. 125 133.

Park, J., Kim, Y., Kim, P.-K., Daniels, H.V., 2011. Effects of two different ozone doses on seawater recirculating systems for black sea bream Acanthopagrus schlegeli (Bleeker):

Removal of solids and bacteria by foam fractionation, Aquacult. Eng. 44, 19-24.

Piper, R.G., Mc Elwain, I.B., Orme, L.E., Mc Craren, J.P., Fowler, L.G., Leonard, J.R., 1982. Fish hatchery management. U.S. Fish and Wildlife service, Washington, DC, 517 p.

Rawat, I., Ranjith Kumar, R., Mutanda, T., Bux, F., 2011. Dual role of microalgae:

Phycoremediation of domestic wastewater and biomass production for sustainable biofuels production. Appl. Energ. 88, 3411-3424.

Roque d'orbcastel, E., Blancheton, J.P., Belaud, A., 2009. Water quality and rainbow trout performance in a Danish Model Farm recirculating system: Comparison with a flow through system. Aquacult. Eng. 40, 135-143. 
Rubio, J., Souza, M.L., Smith, R.W., 2002. Overview of flotation as a wastewater treatment technique. Miner. Eng. 15, 139-155.

Sharrer, M.J., Summerfelt, S.T., Bullock, G.L., Gleason, L.E., Taeuber, J., 2005. Inactivation of bacteria using ultraviolet irradiation in a recirculating salmonid culture system. Aquacult. Eng. Vol. 33, 135-149.

Suantika, G., Dhert, P., Rombaut, G., Vandenberghe, J., De Wolf, T., Sorgeloos, P., 2001. The use of ozone in a high density recirculation system for rotifers, Aquaculture, 201, 35-49.

Suantika, G., Dhert, P., Sweetman, E., O'Brien, E., Sorgeloos, P., 2003. Technical and economical feasibility of a rotifer recirculation system, Aquaculture, 227 (1-4), 173-189.

Summerfelt, S.T., 1999. Waste handling systems. In: Bartali, E.H., Wheaton, F.W. (Eds.), CIGR Handbook of Agricultural Engineering: Animal Production and Aquacultural Engineering, vol. II. American Society of Agricultural Engineers, St. Joseph, MI, pp. 309350.

Summerfelt, S.T., 2006. Design and Selection of Biological Filters for Freshwater and Marine Applications, Aquacult. Eng. 34, Issue 3, p. 275-302.

Suzuki, Y., Hanagasaki, N., Furukawa, T., Yoshida, T., 2008. Removal of bacteria from coastal seawater by foam separation using dispersed bubbles and surface-active substances, $J$. Biosci. Bioeng. 105(4), 383-388.

Teixeira, M.R., Rosa, M.J., 2006. Integration of dissolved gas flotation and nanofiltration for M. aeruginosa and associated microcystins removal. Water Res. 40, 3612-3620.

Teixeira, M.R., Sousa, V, Rosa, M.J. 2010. Investigating dissolved air flotation performance with cyanobacterial cells and filaments. Water Res. 44, 3337-3344.

Timmons, M.B., 1994. Use of foam fractionation in aquaculture. In: Timmons, M.B., Losordo, T.M. (Eds.), Aquaculture Water Reuse System: Engineering Design and Management. Elsevier, Amsterdam, pp. 247-279. 
Timmons, M.B., Chen, S., Weeks, N.C., 1995. Mathematical model of a foam fractionator used in aquaculture. J. World Aquacult. Soc. 26, 225-233.

Timmons, M.B., Ebeling, J.M., 2010. Recirculating Aquaculture $2^{\text {nd }}$ Ed. Cayuga Aquaculture Ventures, Ithaca, NY, USA, $948 \mathrm{p}$.

Figure captions:

Figure 1: The vacuum airlift experimental set-up.

Figure 2: $\mathrm{POM}$ concentration (average $\pm \mathrm{SD}, \mathrm{n}=3$ ) in the rearing tank water and in the foam, before or after feeding, for different airflow rates $\left(10\right.$ or $\left.80 \mathrm{~L} \mathrm{~min}^{-1}\right)$, hourly water renewal rate of $50 \%$ and foam extraction flow of $40 \mathrm{~L} \mathrm{~h}^{-1}$.

Figure 3: POM concentration (average $\pm \mathrm{SD}, \mathrm{n}=3$ ) in the rearing tank water and in the foam, before or after feeding, for different hourly water renewal rates $(100,50$ or $10 \%)$, with a microbubbling airflow rate of $10 \mathrm{~L} \mathrm{~min}^{-1}$ and a foam extraction flow of $40 \mathrm{~L} \mathrm{~h}^{-1}$.

Figure 4: $\mathrm{POM}$ concentration (average $\pm \mathrm{SD}, \mathrm{n}=3$ ) in the rearing tank water before feeding, for 3 consecutive days (D1, D2 and D3) and at different hourly water renewal rates (100, 50 and $10 \%)$.

Figure 5: POM Concentration factor (average $\pm \mathrm{SD}, \mathrm{n}=3$ ) obtained in rearing conditions, before or after feeding, at different hourly water renewal rates (100,50 and $10 \%)$, with a microbubbling airflow rate of $10 \mathrm{~L} \mathrm{~min}^{-1}$ and a foam extraction flow of $40 \mathrm{~L} \mathrm{~h}^{-1}$.

Table legends: 
Table 1: Foam fractionation efficiency (average $\pm \mathrm{SD}, \mathrm{n}=3$ ) and Concentration Factor (average $\pm \mathrm{SD}, \mathrm{n}=3$ ) of fragmented fish pellets achieved by the vacuum airlift after 4 hours with a microbubbling airflow rate of $10 \mathrm{~L} \mathrm{~min}^{-1}$ and an extracted foam volume of $160 \mathrm{~L}$.

Table 2: POM production (average $\pm \mathrm{SD}, \mathrm{n}=3$ ) calculated using mass balance equation (Eq. 4) at different water renewal rates. 


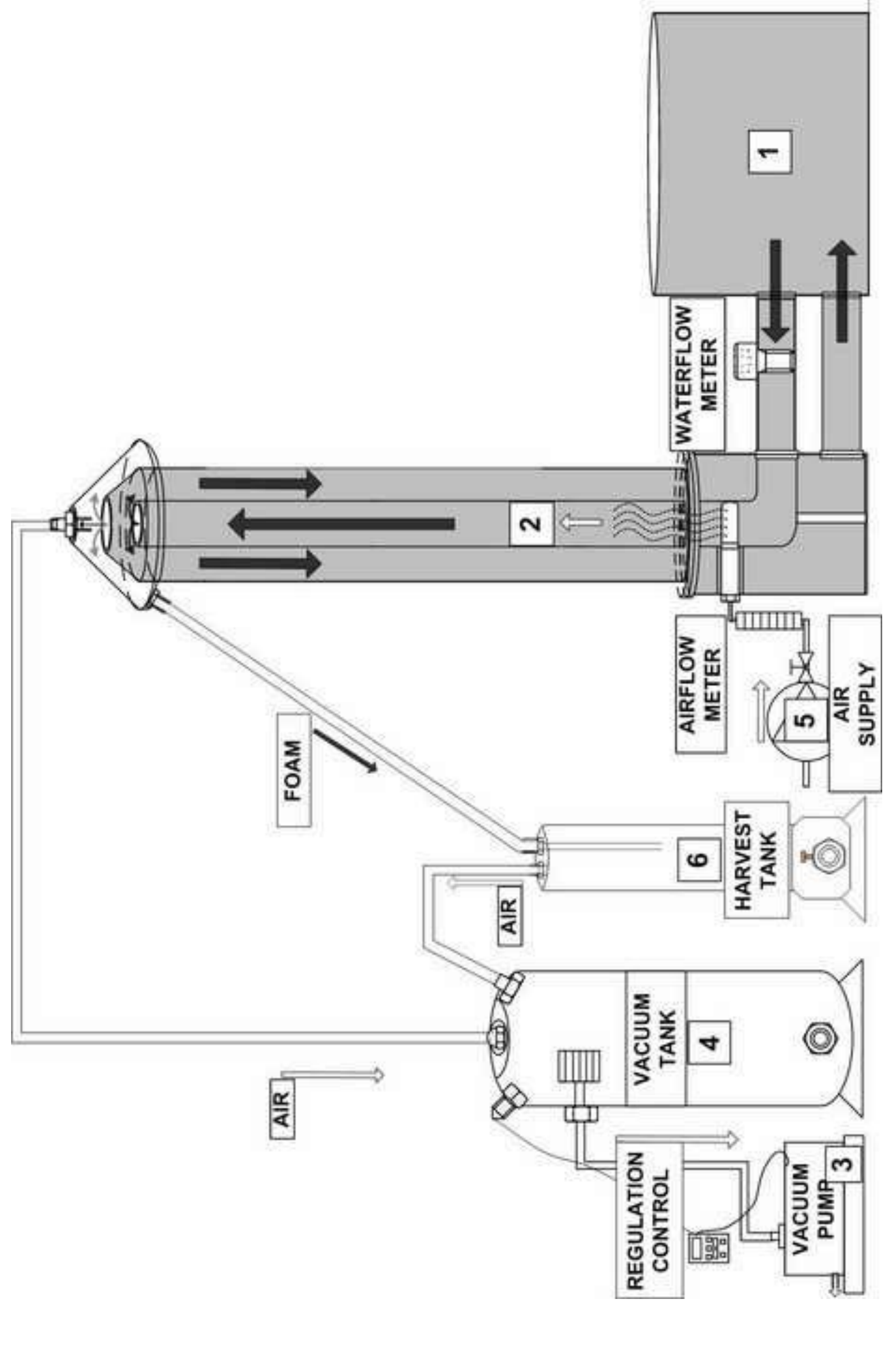


Figure 2

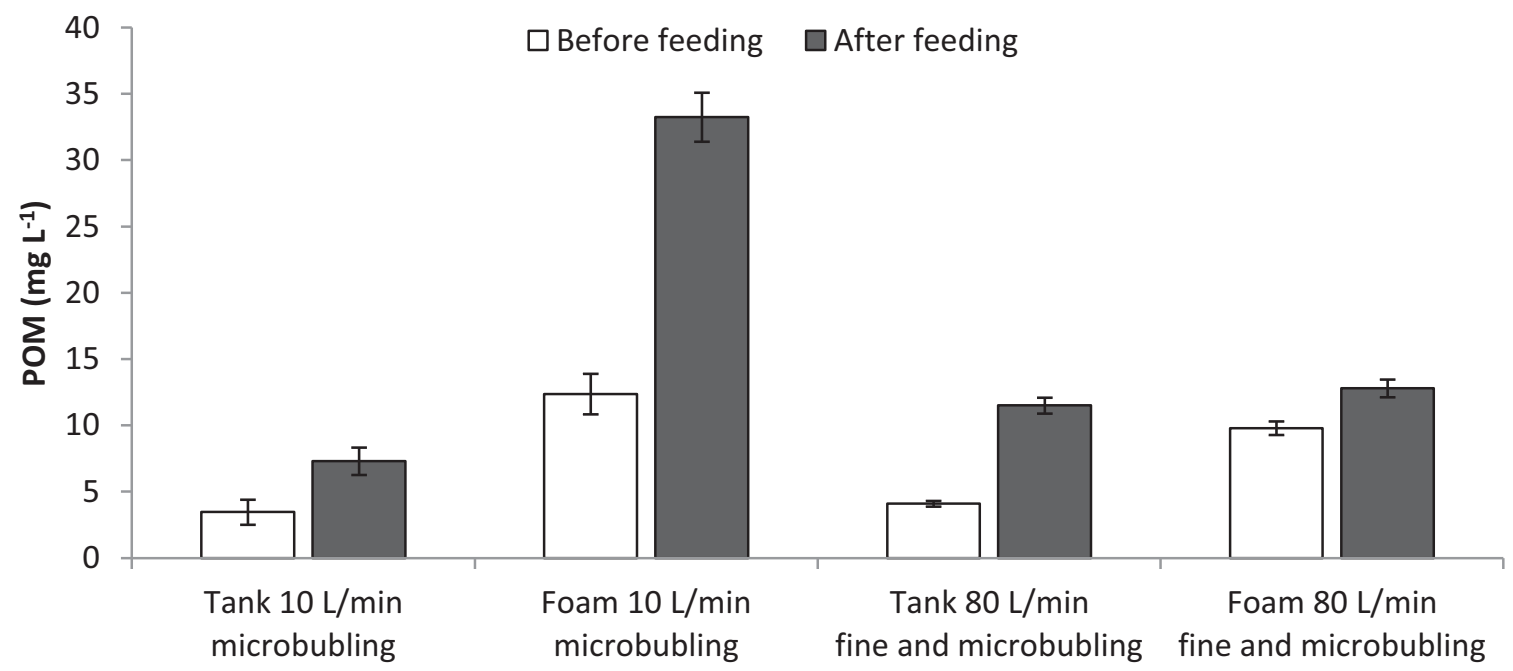


Figure 3

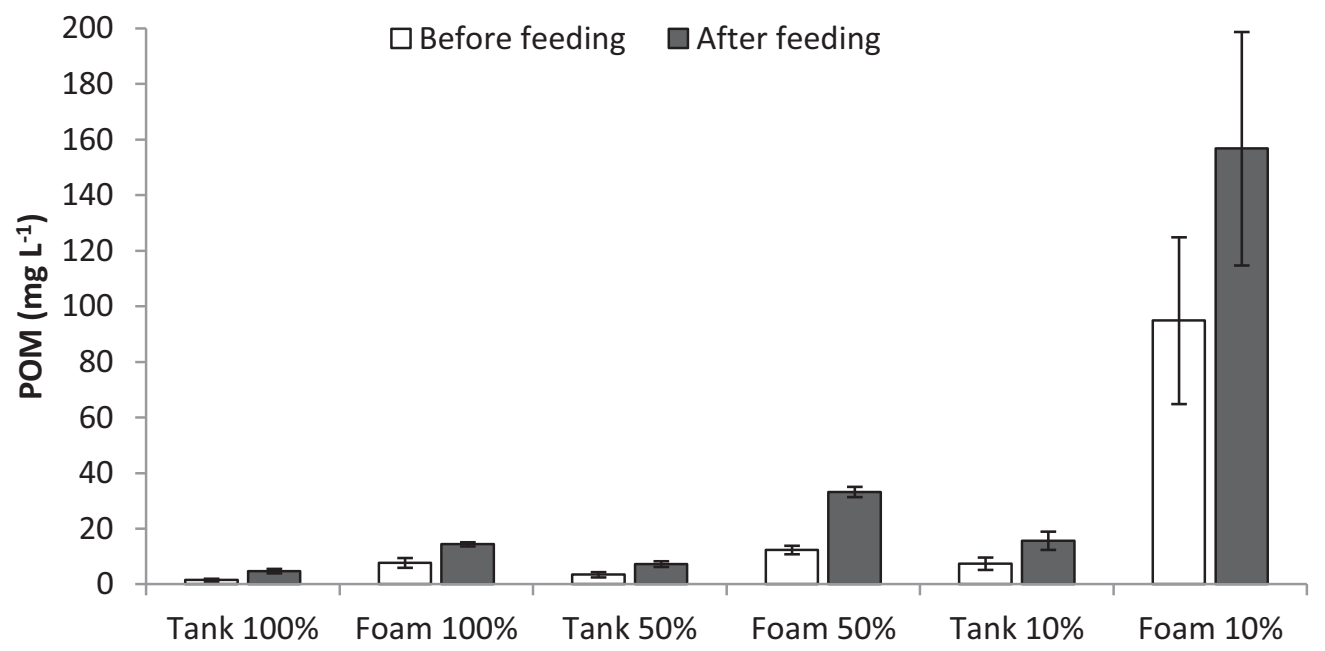


Figure 4

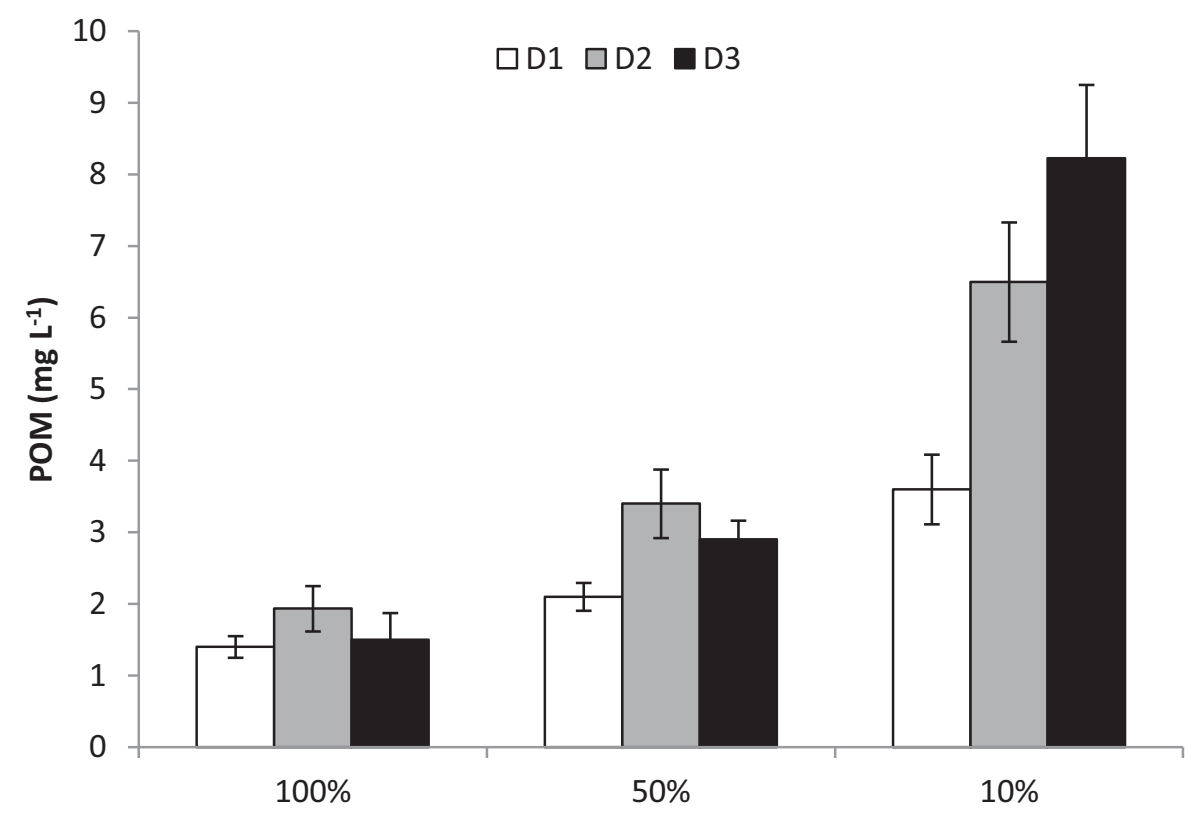


Figure 5

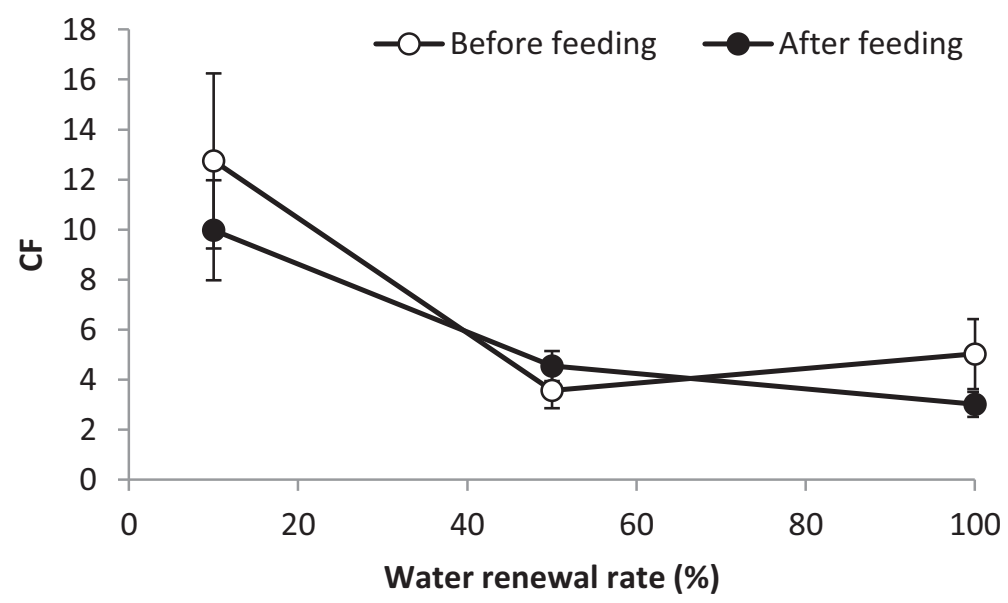

Water renewal rate (\%) 


\begin{tabular}{c|c|c}
\hline & $\mathrm{t}_{0 \mathrm{~h}}$ & $\mathrm{t}_{4 \mathrm{~h}}$ \\
\hline $\begin{array}{c}\text { POM concentration } \\
\text { in the tank }\left(\mathrm{g} \mathrm{L}^{-1}\right)\end{array}$ & $0.105 \pm 0.09$ & $0.025 \pm 0.004$ \\
\hline $\begin{array}{c}\text { POM weight in the } \\
\text { tank (g DW) }\end{array}$ & $118.1 \pm 10.0$ & $23.6 \pm 4.1$ \\
\hline $\begin{array}{c}\text { POM concentration } \\
\left.\text { in the foam (g L }{ }^{-1}\right)\end{array}$ & - & $0.514 \pm 0.043$ \\
\hline $\begin{array}{c}\text { POM weight in the } \\
\text { foam (g DW) }\end{array}$ & - & $94.5 \pm 16.5$ \\
\hline $\begin{array}{c}\text { Concentration Factor } \\
(\mathrm{CF})\end{array}$ & - & $80.7 \pm 3.6$ \\
\hline $\begin{array}{c}\text { Foam fractionation } \\
\text { efficiency }(\%)\end{array}$ & - & $80.0 \pm 13.4$ \\
\hline
\end{tabular}




\begin{tabular}{c|c|c|c|c|c}
\hline Water renewal rate (\%) & $\begin{array}{c}\mathrm{Q}_{\text {out }} \\
\left(\mathrm{m}^{3} \mathrm{~h}^{-1}\right)\end{array}$ & $\begin{array}{c}\mathrm{C}_{\text {out }} \\
\left(\mathrm{g} \mathrm{m}^{-3}\right)\end{array}$ & $\begin{array}{c}\mathrm{Q}_{\text {foam }} \\
\left(\mathrm{m}^{3} \mathrm{~h}^{-1}\right)\end{array}$ & $\begin{array}{c}\mathrm{C}_{\text {foam }} \\
\left(\mathrm{g} \mathrm{m}^{-3}\right)\end{array}$ & P $_{\text {POM calculated }\left(\mathrm{g} \mathrm{h}^{-1}\right)}$ \\
\hline 100 & 15 & 1.5 & 0.05 & 7.7 & $23.4 \pm 6.5$ \\
50 & 7.5 & 3.5 & 0.05 & 12.4 & $26.6 \pm 5.3$ \\
10 & 1.5 & 7.4 & 0.05 & 94.9 & $15.9 \pm 4.9$ \\
\hline
\end{tabular}



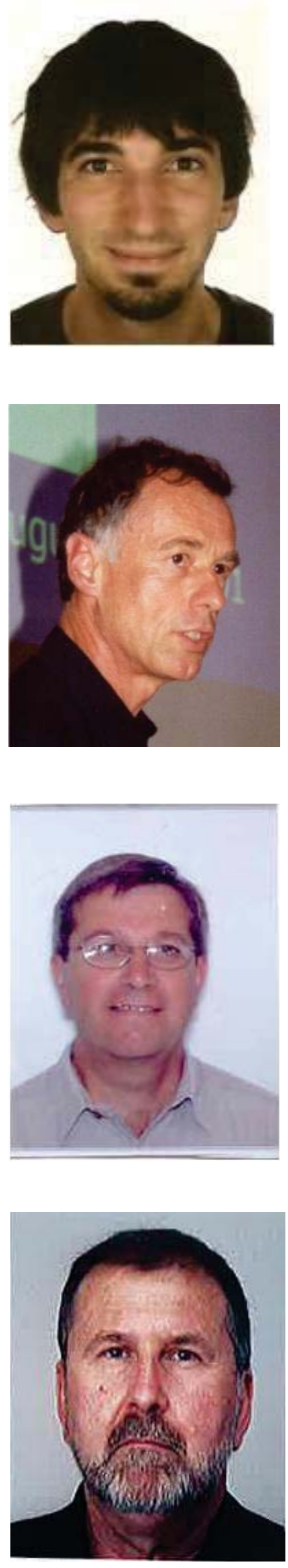

Bertrand Barrut is a $\mathrm{PhD}$ student at the University of Montpellier II. This paper is part of his $\mathrm{PhD}$ thesis in aquaculture at the marine aquaculture centre of ARDA (Reunion Island, France) and at the aquaculture centre of IFREMER (Palavas les Flots, France). "Study and modelling of an innovative water treatment process: the vacuum airlift"

Jean Paul Blancheton is a senior scientist working in IFREMER, at the aquaculture research station of Palavas les Flots, France. He is currently carrying out research on aquaculture production systems in the research teams ,Laboratoire deaquaculture du LanguedocRoussillon and „Unité Mixte de Recherche UMR 5119e Ecosym.

Alain GRASMICK is professor in Chemical Engineering in "Polytech' Montpellier", the Engineering School of Montpellier University. He has studied intensive processes applied to water and wastewater treatment for more than 35 years.

Jean-Yves CHAMPAGNE is professor in hydraulic, working at INSA de Lyon, National Institute of Applied Sciences, in Mechanical engineering. He make his research at LMFA, Fluids Mechanics and Acoustic Laboratory, Unité Mixte de Recherche du Centre National de la Recherche Scientifique, UMR CNRS 5509. 